\title{
データベース「事始め」
}

\section{At the Beginning of Database Industry}

\author{
奥住啓介
}

Keisuke OKUZUMI

オクズミオフイス

干272-0035 千葉県市川市新田2-18-9

E-mail: kei_okuzumi@wine.ocn.ne.jp

データベース（以下DB）が一般市民には馴 染みが薄かった1980年（昭和55年）代，どの ようにDB構築・利用を促進してきたかを，そ の初期の活動を, 関係者の一人として個人的 な視点でまとめた。

80 年代, 我が国は高度経済成長の真只中で, 国民は将来に大きな希望を抱いていた. 国も， 情報処理産業が今後大きく発展していくで あろうことを期待して様々な政策を展開し た. DBもその一つとなり, 当時の振興策の常 套手段として国に代わって事業推進する民 間機関・財団法人データベース振興センター （以下DPC）を 84 年4月に通産省（通商産業省 現経済産業省) が主導して設立したのである。

だが, 既にDBを事業化し企業向けにサービ スしていた事業者で設立されたデータベー スサービス産業懇談会 (その後日本データベ 一ス協会 以下DINA)があった. 当時(今も), 通産省と郵政省間との情報処理産業の所管 争奪もあり, DINAは, 中立を保つ任意団体と していた.そこへ, 官製DPC設立となったこと から相当の反発があった。この問題は関係者 間の話し合いで解決され，DPC設立ののち両 団体は密接な関係を結び, 展示会やセミナー などを共同実施したのである。
DPCの事業は, DB構築・技術開発促進, DB クリアリング, 調查研究, 啓蒙・普及, 国際 交流で構成され, その活動は主に学識経験者 やDB事業者からなる委員会で事業内容の検 討・評価がなされた。当初のDPCは独自の陣 容では知識も経験の不足していたため, 外部 からの参画・支援が必至であり，とくに本学 会員の方々にも多大なご協力を頂いた.

初代理事長は元日本経済新聞社社長の円 城寺氏（故人）であったが，実質的な運営は 専務理事・渡辺龍雄氏 (故人)に委祆られた。 渡辺氏は通産省退職後に着任し, 前職時のネ ットワークを活かして事業の足固めと活動 範囲を広めた。例えば通産省への情報政策立 案時の支援, 各省庁の情報処理担当責任者と の情報交換, 自民党内に設置された情報産業 振興議員連盟・DB対策委員会への情報提供 レクチャー, 他団体や民間企業の情報化支援 などがあげられる. 現在ではこのような動き は考えられないことだが，その当時としては 政官民との密接な連携は不可欠なものであ るとの渡辺氏の持論によるもので,これが受 け入れられた時代でもあった。

渡辺氏がとくに事業の中で力をいれてい たのが国際交流であった. 幾度となく通産省 を通じて, 欧米や他の国々との外交会議で日 
本の情報が入手しにくいとの批判が出てい ることを耳にし, 日本情報の海外提供を充実 させることで問題を解決するとともに, 日本 の正しい理解につながると判断した結果, 国 際交流に重点をおいたのである. 開発途上国 へのDB構築支援もこの活動に含まれていた。 経済成長により企業などの海外展開が進 むなか, 金と人は海外に流れたが情報は未だ 不十分な状況であり，逆に海外 (欧米) から の情報は容易に大量に入手できた時代であ った.これらの要因が海外での日本情報への 批判を生んだが, 一方では理不尽な海外圧力 として” over the counter” の要求もあると 外務省担当官から聞いたこともあった。

そこで，88年頃から欧米・アジアでの日本 情報に関する国際会議への出席, DB展示会へ の出展, DB技術専門家派遣, 南米への技術調 查などを行ったが, 不思議なことに渡辺氏は これらには中国を除き一切参加することは なかった.筆者はこれについて聞いたところ 「志は高く」，「細かいこと (専門分野) は 他人 (専門家) に」との回答であった。これ は，ものごとを始める当初からある程度の期 間は，目的達成のために自己信念に基づき， 強引と思えるほど組織と人を引っ張ってい くことが必要なのであると筆者は解釈した. 90年までは好景気を反映した潤沢な予算 を使い, DB構築・技術開発支援では主に CD-ROM，企業内オンラインでのサービスや， DB事業者のコンテンツ整備が対象の主体で あった. 支援したプロジェクトの中には当時 の成果を継承し, 提供形態がインターネット に変わったものの現在もサービスしている ものもある.また地域での情報化推進のため 地方へも支援したが，その成果と効果は影が 薄かった. 啓蒙普及では刊行物としてデータ ベース白書, データベース台帳総覧を発行し
た. 白書や台帳は新聞に何度も掲載され，ま た学術論文にも引用されたことで, DB産業の 動向を周知するだけでなく学術的にも価值 があったと思っている。これらの刊行物を英 文に翻訳し前述の国際会議, 展示会などで配 布したが概ね好評であった。

92年頃迄のいわゆる「バブル景気」のなか, 電気通信事業法改正，著作権法改正（DB著作 権），国の統計データ公開, DB準備金制度（税 制優遇措置）などの追い風があり，DB産業は 着実に発展をしてきた.91年にはDB産業の売 上高は2000億円を超え, 国産DBは1000近くま で増えた。さらに89年から開催した「データ 一ベース フェア」では 100 社近くの出展に 3 万人の入場者があり, DBは身近なものとなっ てきたのであった。

しかしながら93年ころから「バブル崩壊」 が始まり経済活動の萎縮が目立ち, 加えてイ ンターネットの出現により環境が大きく変 化しのである. 従来のパソコン通信は衰退し CD-ROM化も落ち込み, さらDB事業者はインタ 一ネットへの対応に迫られた。だが，これら の事象は結果論ではあるが良かったと言え よう.インターネットでのサービスによりユ 一ザーが格段に増え, 提供情報方法や内容が 多様化され構築・利用が格段に促進されたの である。

2003年頃からインターネットは巨大なDB といわれ始め，DPCの役目も果たしたのでは との見方も出, 政策転換時期とも重なり, DPC の幕引きに向かった。設立当初, 2000 年のDB 産業売上が3兆4千億円になるとの予測值 $(87$ 年業構造審議会資料）には達しなかったが， DB振興には寄与したと確信している.

そして2006年にDPCは解散し, 奇しくも DINAも同じ運命を辿った. 組織は永遠ではな く，目的が達成されれば消え去るのである. 